DOUGH MODELING: A SENSITIVE STRATEGY FOR DATA COLLECTION IN HEALTH AND NURSING RESEARCH ${ }^{1}$

\author{
Marizete Argolo Teixeira², Mirian Santos Paiva3a, Sheva Maia Nóbrega ${ }^{4}$, Rosane Gonçalves Nitschke ${ }^{5}$
}

\footnotetext{
${ }^{1}$ Extracted from the thesis - Women's seropositivity to HIV and HTLV virus: meanings of the breast milk spread, presented to the School of Nursing at the Federal University of Bahia (EEUFBA), 2009.

${ }^{2}$ Ph.D. in Nursing. Adjunct Professor in the Department of Health at the State University of Southwest Bahia. Salvador, Bahia, Brazil. E-mail: marizete88@yahoo.com.br

${ }^{3}$ Ph.D. in Nursing. Associate Professor, Department of Community Nursing, Federal University of Bahia. Salvador, Bahia, Brazil. E-mail: paivamirian@hotmail.com

${ }^{4}$ Ph.D. in Social Psychology. Adjunct Professor, Department of Psychology at UFPE. Salvador, Bahia, Brazil. E-mail: shevamaia@ hotmail.com

${ }^{5}$ Ph.D. in Nursing Philosophy. Professor, Department of Nursing at the Federal University of Santa Catarina. Florianópolis, Santa Catarina, Brazil. E-mail: rosanenitschke@gmail.com
}

\begin{abstract}
The objective is to report on the experiment of the use of Dough Modeling, while a projective technique, as a strategy for data collection in the qualitative research in health and nursing. Hence, this research was performed based on the Theory of Social Representations, in Salvador, Bahia, Brazil, with 30 women. The technique consisted of offering modeling dough to women who, while handling it, brought the significance of the contamination of human breast milk by virus, reporting it verbally. The results showed that women expressed not only tactile sensations but also visual and emotional sensations, materialized in the modeling, presenting the meaning immersed in their imaginary. The technique allowed expression of creativity and sensitivity, because through the art of modeling, women showed latent emotional content, and was proven to be a projective technique that is sensitive, affective and effective strategy of data collection for qualitative research in the area of health and nursing.
\end{abstract}

DESCRIPTORS: Qualitative research. Data collection. Projective techniques. Nursing.

\title{
MANUSEIO COM MASSA DE MODELAR: UMA ESTRATÉGIA SENSÍVEL DE COLETA DE DADOS NA PESQUISA EM SAÚDE E ENFERMAGEM
}

\begin{abstract}
RESUMO: Objetiva-se relatar a experiência da utilização do Manuseio com Massa de Modelar, enquanto técnica projetiva, como estratégia de coleta de dados na pesquisa qualitativa em saúde e enfermagem. Para tal, traz-se a vivência de uma pesquisa, fundamentada na Teoria das Representações Sociais, realizada em Salvador, Bahia, Brasil, com 30 mulheres. A técnica consistiu em oferecer massa de modelar às mulheres que, no seu manuseio, trouxe o significado do contágio do leite materno por vírus, relatando-o verbalmente. Os resultados mostraram que as mulheres expressaram sensações não só tácteis, mas, também, visuais e emocionais, materializadas nas modelagens, apresentando o significado imerso em seu imaginário. A técnica possibilitou expressão da criatividade e sensibilidade, pois através da arte de modelar, as mulheres evidenciaram conteúdos afetivos latentes, tendo se mostrado, enquanto técnica projetiva, como uma estratégia sensível, afetiva e efetiva, de coleta de dados para a pesquisa qualitativa na área da saúde e da enfermagem.

DESCRITORES: Pesquisa qualitativa. Coleta de dados. Técnicas projetivas. Enfermagem.
\end{abstract}

\section{MANIPULACIÓN CON PLATILINA: UNA ESTRATEGIA PARA LA RECOLECCIÓN DE DATOS SENSIBLES EN LA INVESTIGACIÓN EN ENFERMERÍA Y SALUD}

\begin{abstract}
RESUMEN: El objetivo es dar a conocer la experiencia de uso de plastilina, mientras que la técnica proyectiva como una estrategia para la recolección de datos en la investigación cualitativa en salud y Eenfermería. Para ello, se presentan las experiencias de una investigación, basada en la teoría de las representaciones sociales, que se realizó en Salvador, Bahia, Brasil, con 30 mujeres. La técnica consistió en la oferta de plastilina a las mujeres, quienes en su manipulación, trajo el significado del contagio viral por medio de la leche materna, relatando los temores verbalmente. Los resultados mostraron que las mujeres expresan sentimientos no sólo táctiles, sino también visuales y emocionales, materializados en la plastilina y presentando el significado inmerso en su imaginación. La técnica permitió la expresión de la creatividad y la sensibilidad, porque a través de la técnica de modelado, las mujeres mostraron un contenido latente emocional y se ha demostrado como una técnica proyectiva, como una estrategia sensata, recopilación de datos afectiva y efectiva para la investigación cualitativa en el ámbito de la salud y Eenfermería.
\end{abstract}

DESCRIPTORES: Investigación cualitativa. La recolección de datos. Las técnicas proyectivas. Enfermería. 


\section{INTRODUCTION}

The methodology is understood as the appropriate path and instrument to approach reality. It includes theoretical conceptions of approach, a set of techniques that enable the apprehension of reality, besides the creative potential of the researcher. It is more than a description of the methods and techniques to be used; it indicates the alternatives and the operational reading that the researcher made of the theoretical framework, not just contemplating the exploratory phase in the field, but also the definition of tools for data analysis. ${ }^{1-2}$

The methodological approach is a guide for the researcher to actually walk along the path throughout the study. It needs to be appropriate to the type of object that is being researched, as well as the goals meant to be achieved. Moreover, it still needs to be consistent with the theoretical framework adopted; after all, "the methodology is not the same for all processes of investigation". 3:163

Thus, the methodology is the art of directing the study using methods, techniques and procedures with the aim of achieving the proposed objectives. The items constituting the methodology are the type of study, the location of the study, the techniques and tools for data collection, determining the sample or participants, analysis procedures and the ethical and legal aspects.

All these stages are of great importance in guiding the research. Each one with its own importance, yet, being interdependent in the intertwining of the activities and knowledge in the construction of new knowledge. Hence, the objective of this study is to report on the experiment about the use of Dough Modeling (DM), while a projective technique, as a strategy for data collection in the qualitative research in health and nursing. To this end, a clipping of a thesis is brought, ${ }^{4}$ whose theoretical basis was the Theory of Social Representations (TSR). This theory has been widely used into the social research in health, since the social representations about a particular object, event or situation, guide, organize and determine the behaviors and practices.

Research involving the imaginary and, especially, those anchored in TSR may use a variety of tools and techniques for data collection, thus enabling a combination that ensures the grasping of information that complements each other, contributing to ensuring a more accurate analysis of the results.

Thus, when using the TSR framework as the theoretical basis, the multi-method approach was chosen, aiming at the representations identified through a survey, projective techniques, an interactive dynamic and semi-structured interviews, emphasizing that "researchers must develop procedures as they go", thereby "without following a specific linear design and following the natural properties of their field". $5: \mathrm{VII}$

Thus a rescue is made of the idea of the field investigator being a "strategist", suggesting that the research process is developed around strategies. Thus, strategies can occur in a non-linear way, "almost simultaneously and integrated". $5: \mathrm{VII}$

Is worth emphasizing that, in research with families, in context, there is the "relevance of the integration and combination of strategies considered as sensitive in the research process" 6:60

Considering the aforementioned aspects, a question emerged: what is the effectiveness of the DM technique as a projective technique and strategy for data collection, in qualitative research in nursing and health care?

Seeking to answer this question, this paper reports on the experience of using the DM technique, considered as a projective technique, presented herein as a strategy for data collection, to develop qualitative research in health and nursing.

\section{PROJECTIVE TECHNIQUES}

Projective techniques are strategies for data collection with specific objectives to obtain latent, unconscious and content considered very important due to the depth of the data and the meanings, hardly obtained by other techniques. Its applicability consists of guiding questions, whose answers are presented indirectly through symbols, metaphorically, making people reveal hidden content that would not be manifested either directly or deliberately, bringing forth their imaginary. Projective techniques are distinguished from other tools by the ambiguity of the material presented and the freedom that is given to the subject to express his or her latent and hidden subjectivity.

Projective techniques enable the emergence of meanings from the underlying relationships between human beings and, at the same time, 
their relationships with the world they experience. Through them, people can project what they believe to be, what they wish to be and, above all, what they refuse to be or should be in relation to themselves and to others. Furthermore, these techniques are recommended when the object of investigation involves obtaining information that could not be accessed directly by people or groups, in that they consist of problems situated in conflictgenerating psychosocial spheres. ${ }^{8}$

Thus, projective techniques are valuable tools and strategies for data collection, due to their importance in the use of understanding the imaginary and social representations, especially when working with themes that are difficult to be expressed by the subjects. However, it should be noted that projective techniques are valuable when analyzed together with other techniques that are not projective. ${ }^{8}$

Below, the context in which the research was developed and the DM technique will be presented, discussing the main features, including how it was applied in the thesis entitled - "Women's seropositivity to HIV and HTLV virus: meanings of the breast milk spread".

\section{METHOD}

\section{The context of the research}

The reported experience occurred when carrying out a qualitative exploratory-descriptive research with the goal of understanding the social representations of contamination of human breast milk by HIV (Human Immunodeficiency Virus) and HTLV (Human T-Lymphotropic Virus). The investigation was developed in the city of Salvador, Bahia, Brazil, a city of approximately three million inhabitants. A State Reference Center for STD/ AIDS, a Reference Center for HTLV and the prenatal service of a Basic Health Unit comprised the setting of this research.

A total of 198 women took part in this research, of whom 64 were seronegative, 70 seropositive for HIV and 64 seropositive for HTLV, regardless of the condition relating to breast-feeding, the age and number of children, chosen randomly, and whom agreed to participate in the study. Nevertheless, the DM technique was applied on only 30 women, 10 being seronegative, 10 seropositive for HIV and 10 seropositive for HTLV.
The other techniques used were: the Free Word Association Test (FWAT), answered by 120 women; an interactive dynamic, specially created to collect data in this study, of which 72 women participated.

All ethical premises were complied with throughout the research process, since there was concern about the values brought by each woman. This is because "ethics involve judgments in appreciation, i.e., it involves a judgment and a decision. Hence, it involves consciousness, and consciousness is the attribute by which man is taken as regards the world and its interior". 9:17 Therefore, ethics are something subjective, depending on the conscientious judgment of each person; it is an individual judgment.

Thus, after institutional approval, the project was submitted to the Research Ethics Committee at the School of Nursing at the Federal University of Bahia (CEP/EEUFBA), in January 2008, and was approved by review 001/2008, considering the ethical principles involving human research, established by Resolution 196/96 of the National Health Council. ${ }^{10}$ Therefore, the anonymity and privacy of the information were guaranteed, as well as respect for human dignity, required in all research, and carried out only after the informed consent of the subjects who expressed their agreement to participate in the research.

\section{The dough modeling technique}

In 2005, one of the authors developed a dissertation, ${ }^{11}$ with the influence of grandmothers on breast-feeding being its object of study. This was the first time that the author used modeling dough as one of the techniques for data collection, which, at that time, was known as a creative dynamic to capture the imaginary, identifying the meaning of breast-feeding for the informants in the research - grandmothers. This dynamics constituted an important tool for understanding these meanings and imagery, as well as implementing the Nursing Care Model for the family in the breast-feeding process.

After three years, when outlining the methodological approach in the doctoral thesis, ${ }^{4}$ the author used this creative dynamic, and named it the dough modeling technique, abbreviated at the time as MCMM (acronym for Manuseio com Massa de Modelar, which stands for handling with modeling dough), and, subsequently, MMM (which 
stands for Handling Modeling Dough - HMD). Once again, this technique consisted of a valuable tool for understanding the social representations of the group of women informants from the new research, since the research contributed to the investigation of information with hidden and unconscious content, which the informants could only express from expressive-motor processes (Handling of Modeling Dough) and perceptualdynamic processes (verbalization of what was modeled).

The DM technique consisted of placing modeling dough of different colors at the disposal of the women. Then the guiding question was made: what does the contamination of breast milk with HIV and HTLV viruses mean to you? At this point, they were instructed that they could only answer the question though the modeling. Thus, from the modeling dough available, they could think of ways of materializing what the contamination of human breast milk by virus meant to them. The few moments that they took to begin modeling were carefully observed, as these moments were important to notice movements, gestures, facial expressions and spoken words. After the modeling was finished, a verbal report on what had been modeled was requested. The speeches were recorded, transcribed and analyzed together with the image of the models.

\section{Analyzing the Dough Modeling}

The analysis of the material collected from the DM technique adopted the same model proposed in the thesis ${ }^{4}$, which was constructed taking inspiration from projective techniques, and following two approaches. The first, focusing on the analysis of Drawing-Story with Theme. ${ }^{13}$ The second, considering the semiotic analysis of still images. ${ }^{14}$

However, the DM technique has specific and distinguished characteristics, above all, by the joint production of tactile, visual and emotional sensations in the manifestation of affective content, essentially significant for the analysis of the social representations that emerged from the unconsciousness of women and which were materialized from patterned images, as described below.

1) Systematic observation of the modeling - after performing the technique, the modelings were photographed and saved in a Word 97-2003 document. The photos were then filed in envelopes in a cardboard box with individual identification of the authorship.

2) Choice of modelings for analysis - in this study, we chose to use all of the images resulting from the DM modeling, given the importance in grasping the meaning of the social representations.

3) Selection of the modelings by symbology resemblance - after being photographed, the images were grouped by symbolic resemblance as set out in the comments of women participating in the DM.

4) Denotative inventory - the texts coming from the comments were attached to the images modeled, in which the women described the meaning and the significance of the modeling for them. Thus the denotative stage of the analysis was composed, which involved cataloging the literal sense of the material provided by the women, using the textual elements understood from the denotation: linguistic (words) and imagistic elements, and to describe, in detail, the visual characteristics of the modeling. With regard to the aspect of verbalization on the description of the modeled object, the initial reading of the comments was carried out, always referring to the images of the modelings, as well as listening to the recorded material, so as to let the themes emerge.

5) Analysis of the levels of meaning - this stage was built from the denotative inventory. Therefore, it was necessary to make the elements present in each image as a series of related questions: what connotations are there in that image (which associations are brought to mind)? How do the elements relate to each other (internal matches, contrasts)? What cultural knowledge is required in order to read the material?

Within the scope of denotation, to read what the image expressed, it was necessary to know the written and spoken language. Within the scope of connotation, several aspects of cultural knowledge were necessary, about breast-feeding, not breastfeeding, infection by the HIV and HTLV viruses, the theoretical framework adopted in this study, as well as the knowledge and values of the researchers, readers and the women who participated in the survey.

6) Analysis and interpretation of the themed content grouped by categories, as per the thematic content analysis model, ${ }^{1}$ considering the research objectives and theoretical framework. 
7) Deciding when to stop - it was a difficult stage, since the analysis process never runs out and, therefore, will never be complete, because a new way to read the image is always possible, or a new lexicon or reference system to apply to the image. Nevertheless, the conclusion of the analysis takes place at a certain point in the discussion, when one realizes that the research problem was focused on and that the meanings, significances and feelings were extracted from the images and texts, thus enabling the grasping of the studied phenomenon.

8) Analysis Report - the analysis report was the last step, which was processed in a discursive and illustrative manner, from the categories that emerged from the subjects' statements and images. Therefore, it was necessary to connect the image to the text, which brought contributions for analysis, this because "the image is always polysemic and ambiguous. That is why most of the images are always accompanied by some sort of text: the text takes the ambiguity out of the image [...] where both, images and text, contribute to the full meaning". ${ }^{14: 322}$

The final analysis, expressed in the thesis, has resulted in the emergence of categories and subcategories arising from the organization of the women statements from the DM, mainstreamed by the interactive dynamic and the FWAT. These techniques, integrated to the analysis and the theoretical framework, are constituted as catalyst tools for a critical-reflective type action from the researchers. An explosion of knowledge was thus experienced, to be shared with other collective subjects, contributing, although tentatively, to the evolution of science in this field of learning.

\section{RESULTS AND DISCUSSION}

\section{Some reflections on Dough Modeling}

Women made the meanings of the contamination from human breast milk by viruses observable, materializing them through their modeling. Thus, upon being stimulated with the guiding question, the observable was evidenced by the verbalization about what the modeling made by them meant. Thus, stimulation was necessary to make the modeled image materialize, brought from the imaginary to then obtain the verbal communication and record the expression of the psychological structure of each woman who participated in the DM.

It is worth highlighting that the modeling dough is characterized by its malleability, thus enabling flexibility, a tactile sensation of pleasure and cognitive stimulation to the expression of the unconscious of the artistic self in representing the model. From this perspective, the women developed their perception of the contamination of human breast milk by the HIV and HTLV viruses, when allowing figures and multivariate meanings to emerge from their imaginary, represented by animals (phantasmagoric, from the animal kingdom, such as a snake), human figures (a woman crying, with disfigured faces, without hands), breasts (disfigured, with viruses around them, engorged and without nipples), children (disfigured, dead children), objects (cross, flower, dagger) and the heart.

We believe that the DM was effective as a projective technique. The questions and answers were not direct, rather, they entered the metaphorical field, being objectified and revealing images that emerged from the unconscious. Thus, upon stimulation with the guiding question, women, through their modeling, materialized the meaning of contamination of human breast milk by virus, making it observable and concrete; showing, through their comments, what the modeling done by them meant, thus revealing their imaginary.

Therefore, the psychological structure and the imaginary of the women became palpable through the creations, revealing what was hidden in their unconscious, and, because it is a technique that emerged from the latent content and not filtered by censorship, we can consider DM as a projective technique. We understand that the DM technique can be done individually or in groups, and it can be used with people of all ages, of both sexes, and with different socioeconomic and cultural characteristics.

Only recently, studies involving the use of modeling dough have been found. ${ }^{15-16}$ However, these studies report having used modeling dough to bring out the Social Representations of various subjects, not contemplating, therefore, the analysis of the images modeled in a systematized manner. The images modeled were only selected by similarity to substantiate the empirical categories. 


\section{FINAL CONSIDERATIONS}

The use of the DM technique, characterized as a projective technique, enabled deeper clarification on the subject, showing different levels and facets expressed by the Social Representations. This can be confirmed in the comments of the subjects (more conscious elements), attitudes and values (latent, hidden content), which exceed the contextual standards, revealing counter-normative material from the subjects, contributing to the knowledge of the imaginary.

The DM technique allowed the studied women to project, through creativity with modeling dough, the meaning and significance of contamination of human breast milk. They showed how they are viewed by others and how they would like to be seen, how they lived or experienced being a nursing-mother-woman; expressing the symbolic, the affections and the stigma they faced. Furthermore, the use of DM allowed the capture of Social Representations and the imaginary, especially having worked with a complex and plural study object, as in the case of the theme focused on, i.e., the contamination of human breast milk by the HIV and HTLV viruses.

DM extracted the suppressed affections and repressed emotions from the women's universe, from their imaginary; to bring to light information about the issue in focus. These emotions were expressed in the models built by the women, which allowed the objectification of the Social Representations on the virus, the contamination of human breast milk and the feelings towards not breast-feeding.

Therefore, the DM technique, upon allowing access to the underlying and latent content to the modeled figures, connected to the speeches of the participants, leads us to consistent analysis, showing the relevance when confronted with other methodological strategies used in research.

The adoption of this technique allowed the expression of creativity, sensitivity and spontaneity, reinforcing that, through the art of modeling, women showed affective, hidden and latent content, that do not manifest themselves directly.

Thus, the DM technique proved be a projective technique and a significant, sensitive, affective and effective strategy for data collection in qualitative research in health and nursing, especially those involving the imaginary, such as, for example, studies based on the Theory of Social Representations.

\section{REFERENCES}

1. Minayo MC. O desafio do conhecimento: pesquisa qualitativa em saúde. $7^{a}$ ed. São Paulo (SP) / Rio de Janeiro (RJ): HUCITEC-ABRASCO; 2000.

2. Deslandes SF. A construção do projeto de pesquisa. In: Minayo MC, organizadora. Pesquisa social: teoria, método e criatividade. $21^{\text {a }}$ ed. Petrópolis (RJ): Vozes; 2002. p. 31-50.

3. Beck CLC, Gonzales RMB, Leopardi MT. Detalhamento da metodologia. In: Leopardi MT, organizadora. Metodologia da pesquisa na saúde. $2^{a}$ ed. Florianópolis (SC): Universidade Federal de Santa Catarina, Pós-Graduação em Enfermagem; 2002. p. 163-82.

4. Teixeira MA. Soropositividade de mulheres para os vírus HIV e HTLV: significados do contágio do leite materno [tese]. Salvador (BA): Universidade Federal da Bahia, Programa de Pós-Graduação em Enfermagem; 2009.

5. Schatzman L, Strauss AL. Field research: strategies for a natural sociology. New Jersey (US): PrenticeHall, 1973.

6. Nitschke RG. Mundo imaginal de ser familia saudável: a descoberta de laços de afeto numa viagem no quotidiano em tempos pós-modernos. Pelotas (RS): Universitária UFPel; 1999.

7. Coutinho MPL, Nóbrega SM, Catão MFM. Contribuições teórico-metodológicas acerca do uso dos instrumentos projetivos no campo das representações sociais. In: Coutinho MPL, Lima AS, Fortunato ML, Oliveira FB, organizadores. Representações sociais: abordagem interdisciplinar. João Pessoa (PB): Editora Universitária UFPB; 2003. p.50-66.

8. Coutinho MPL. Depressão infantil e representação social. $2^{\mathrm{a}}$ ed. João Pessoa (PB): Universitária UFPB; 2005.

9. Lima WC. Ética e moral, ética e liberdade, ética e responsabilidade, princípios de bioética. In: Anais do I Seminário de Ética em Pesquisa em Seres Humanos, 2004 Ago 19-20; Florianópolis, Brasil. Florianópolis (SC): UDESCESAG; 2004. p.17-23.

10. Ministério da Saúde (BR), Conselho Nacional de Saúde, Comissão Nacional de Ética em Pesquisa. Resolução ${ }^{\circ} 196$ de 10 de outubro de 1996: diretrizes e normas regulamentadoras de pesquisa envolvendo seres humanos. Brasília (DF): MS; 1996.

11. Teixeira MA. Meu neto precisa mamar! E agora? Construindo um cotidiano de cuidado junto a mulheres-avós e sua família em processo de amamentação: um modelo de cuidar em enfermagem fundamentado no Interacionismo Simbólico 
[dissertação]. Florianópolis (SC): Universidade Federal de Santa Catarina, Programa de PósGraduação em Enfermagem; 2005.

12. Teixeira MA, Nitschke RG. Modelo de cuidar em enfermagem junto às mulheres-avós e sua família no cotidiano do processo de amamentação. Texto Contexto Enferm. 2008 Jan-Mar; 17(1):183-91.

13. Coutinho MPL. Uso de técnicas projetivas na apreensão de representações sociais da sintomatologia da depressão infantil [tese]. São Paulo (SP): Universidade de São Paulo. Programa de Pós-Graduação em Psicologia; 2001.

14. Penn G. Análise semiótica de imagens paradas. In: Bauer MW, Gaskell G, editores. Pesquisa qualitativa com texto, imagem e som: um manual prático. Petrópolis (RJ): Vozes; 2002. p. 319-42.

15. Souza AC. Representações sociais de gênero: uma investigação com crianças de uma escola pública. Rev Entrelinhas. 2012 Jan-Jun; 6 (1):120-6.

16. Souza AC, Figueiredo TAM, Del Priore M. Representações sociais sobre a mulher: um estudo com escolares. Rev Ecos. 2011 Jul; 10 (1):25-31. 